\title{
New and rare aquatic Diptera (Dixidae, Thaumaleidae and Empididae) from Spain and Andorra
}

\author{
R. Wagner ${ }^{1}$ \\ F. $\mathrm{Cobo}^{2}$
}

Keywords : Diptera, Dixidae, Thaumaleidae, Empididae, new species, species list, Spain, Andorra.

Twenty-two species of aquatic Diptera have been collected from 16 sites on the Iberian peninsula. Three Dixidae : Dixa nebulosa Meigen, D. puberula Loew, D. submaculata Edwards; three Thaumaleidae: Thaumalea miki Edwards, T. pyrenaica Edwards, T. verralli Edwards ; and sixteen aquatic Empididae (Hemerodromiinae and Clinocerinae): Hemerodromia adulatoria Collin, $H$. baetica Collin, $H$. gaditana nov. spec., Wiedemannia mirousei Vaillant, W. fallaciosa (Loew), W. hygrobia (Loew), W. digitata Vaillant, W. tiburica nov. spec., Clinocera barbatula Mik, C. madicola Vaillant, C. tenella Wahlberg, C. nigra (Meigen), C. fontinalis (Haliday), C. stagnalis (Haliday), C. wesmaeli Macquart and Dolichocephala ocellata Costa. Two species are new to science and several others are recorded for the first time in Spain or Andorra, although their occurrence was expected because many records were based on collections from the French Pyrenees.

Quelques diptères aquatiques nouveaux ou intéressants (Dixidae, Thaumaleidae et Empididae) d'Espagne et d'Andorre

Mots-clés : Diptera, Dixidae, Thaumaleidae, Empididae, nouvelles espèces, liste faunistique, Espagne, Andorre.

Vingt-deux espèces de diptères aquatiques ont été récoltées dans seize localités de la Péninsule Ibérique. Trois Dixidae : Dixa nebulosa Meigen, $D$. puberula Loew, $D$. submaculata Edwards; trois Thaumaleidae : Thaumalea miki Edwards, $T$. pyrenaica Edwards, $T$. verralli Edwards; et seize Empididae aquatiques (Hemerodromiinae et Clinocerinae) : Hemerodromia adulatoria Collin, H. baetica Collin, H. gaditata nov. spec., Wiedemannia mirousei Vaillant, W. fallaciosa (Loew), W. hygrobia (Loew), W. digitata Vaillant, W. tiburica nov. spec., Clinocera barbatula Mik, C. madicola Vaillant, C. tenella Wahlberg, C. nigra (Meigen), C. fontinalis (Haliday), C. stagnalis (Haliday), $C$. wesmaeli Macquart et Dolichocephala ocellata Costa. Deux espèces nouvelles d'Empididae sont décrites et plusieurs espèces sont une première citation pour l'Espagne ou l'Andorre où leur présence était prévisible, compte-tenu de leur présence dans les Pyrénées françaises.

\section{Introduction}

Data on aquatic Diptera from continental Spain are rare. This is in particular true for the three families processed here. Few Thaumaleidae have been mentioned or described by Schmid (1951) and Vaillant (1968b).

1. Limnologische Fluss-Station des Max-Planck Instituts für Limnologie. P.O. Box 260, D-36105 Schlitz, Deutschland.

E-mail: rwagner@mpil-schlitz.mpg.de

2. Departamento de Biología Animal, Facultad de Biología, Universidad de Santiago de Compostela, E-15782 Santiago de Compostela (A Coruña), Spain.

E-mail: bacobo@usc.es
Early data on dance flies (Empididae, Hemerodromiinae and Clinocerinae) are from Strobl (1899, 1906, 1909), and Séguy (1929). Recent information is available from Vaillant $(1964,1967,1968 \mathrm{c})$, Vaillant \& Chvála (1973), Chvála \& Wagner (1989) and Wagner (1995). For this family there is almost complete information on Mediterranean and Atlantic islands of Spain (Wagner 1995) and Portugal (Wagner \& Stauder 1993). The greater part of information on Iberian Dixidae is from collections in the French Pyrenees (Vaillant 1968a). Comprising the above, our knowledge on the distribution and even the species-stock of the Iberian Peninsula is very limited. Therefore, it was not surprising that even small collections of aquatic Diptera contained new records for individual countries, or 
even species new to Science. However, still no information on all of these groups for continental Portugal is available.

\section{Material and methods}

This study is based exclusively on adult specimens collected at 16 sampling sites distributed throughout Spain and Andorra with sampling sites in the Pyre- nees, Galicia, Andalusia and the province of Cuenca (Fig. 1 ; numbers in parentheses provided for each taxon in the results section correspond to the 16 collecting sites). The altitude of the sampling sites ranges from $300 \mathrm{~m}$ to a maximum elevation of $2100 \mathrm{~m}$.

Collecting methods included the use of hand-nets and ultraviolet light traps. For a proper determination the examination of the male genitalia is necessary.

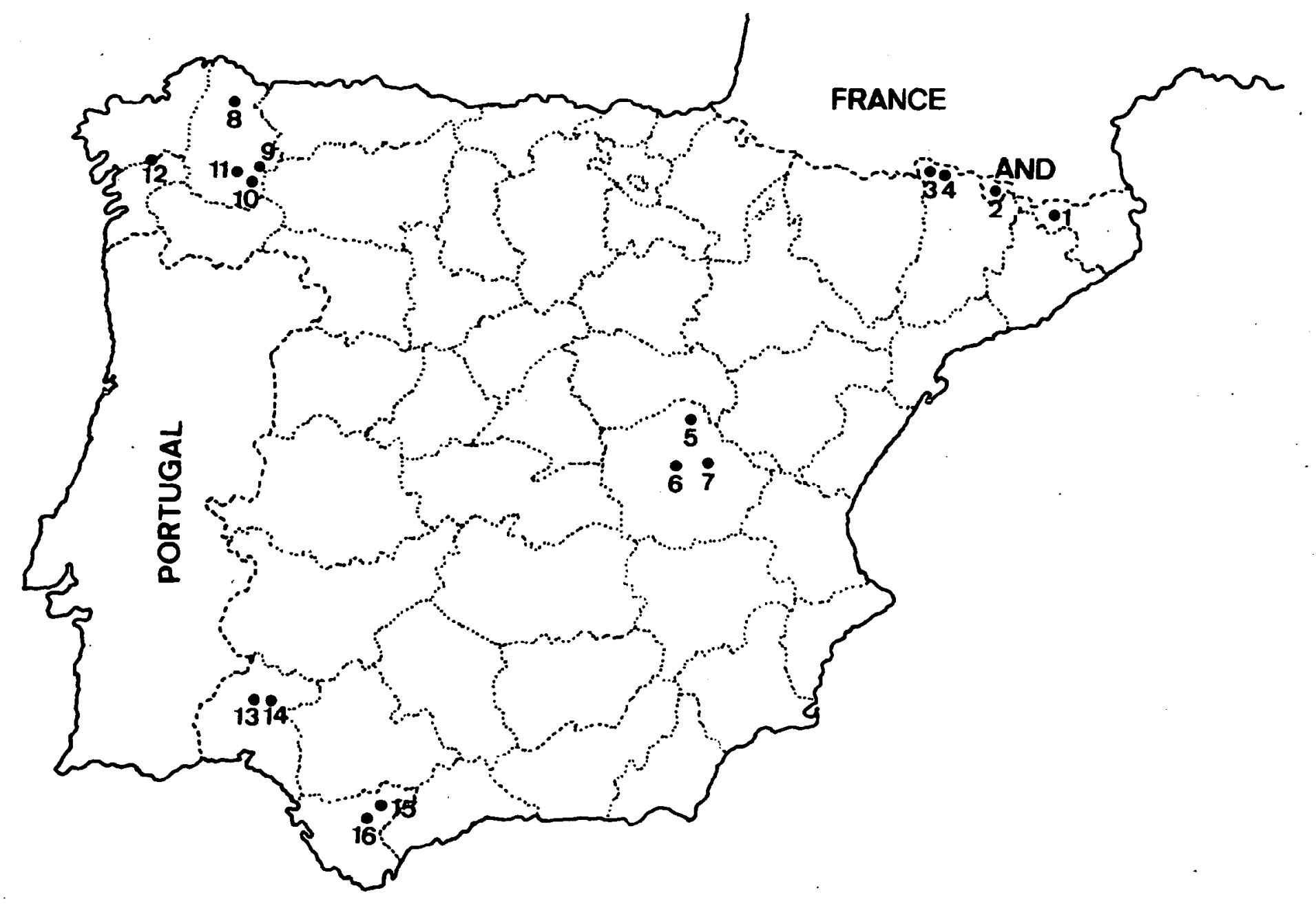

Fig. 1. Location of 16 sampling sites in Spain and Andorra : 1.- Camprodón, river Ter (Girona), $1000 \mathrm{~m}$ a.s.l. 2.- Vall de Ramsol, Andorra, $2100 \mathrm{~m}$ a.s.l. 3.- Fte. de Pomero, Güels del Joeu, Les Bordes, Vall de Arán (Lérida), $1400 \mathrm{~m}$ a.s.l. 4.- Pont del Nere, river Nere, Viella (Lérida) $1400 \mathrm{~m}$ a.s.l. 5.- Lagunillos, river Escabas (Cuenca), $1100 \mathrm{~m}$ a.s.1. 6.- Pinar de Jabaga, Fuentenave de Jabaga (Cuenca), $1080 \mathrm{~m}$ a.s.l. 7.- Uña, river Jucar (Cuenca), $1200 \mathrm{~m}$ a.s.1. 8.- Santa. Mariña, river Landro, Ourol (Lugo), $600 \mathrm{~m}$ a.s.l. 9.- Valdomir, river Lor, Sierra del Caurel (Lugo), $450 \mathrm{~m}$ a.s.l. 10.- Ferreirós, river Ferreirós, Sierra del Caurel (Lugo), $500 \mathrm{~m}$ a.s.l. 11.- Folgoso, Sierra del Caurel (Lugo), $600 \mathrm{~m}$ a.s.l. 12.- Santiso, river Ulla (A Coruña), $320 \mathrm{~m}$ a.s.1. 13.- Campofrío, river Odiel, Sierra de Aracena (Huelva), $340 \mathrm{~m}$ a.s.l. 14.- Rivera de la Nava, river Murtigas (Huelva), $480 \mathrm{~m}$ a.s.l. 15.- Huerta Hedionda, river Tavizna (Cádiz), $320 \mathrm{~m}$ a.s.l. 16.- El Bosque, Sierra de Grazalema (Cádiz), $300 \mathrm{~m}$ a.s.l.

Fig. 1. Carte de répartition des 16 sites de capture (Espagne et Andorre) : 1.- Camprodón, rivière Ter (Girona), $1000 \mathrm{~m}$ a.s.l. 2.- Vall de Ramsol, Andorra, 2100 m a.s.l. 3.- Fte. de Pomero, Gôuels del Joeu, Les Bordes, Vall de Arán (Lérida), 1400 $\mathrm{m}$ a.s.l. 4.- Pont del Nere, rivière Nere, Viella (Lérida) $1400 \mathrm{~m}$ a.s.l. 5.- Lagunillos, rivière Escabas (Cuenca), $1100 \mathrm{~m}$ a.s.l. 6.- Pinar de Jabaga, Fuentenave de Jabaga (Cuenca), $1080 \mathrm{~m}$ a.s.l. 7.- Uña, rivière Jucar (Cuenca), $1200 \mathrm{~m}$ a.s.1. 8.- Santa. Mariña, rivière Landro, Ourol (Lugo), $600 \mathrm{~m}$ a.s.1. 9.- Valdomir, rivière Lor, Sierra del Caurel (Lugo), $450 \mathrm{~m}$ a.s.1. 10.Ferreirós, ruisseau de Ferreirós, Sierra del Caurel (Lugo), $500 \mathrm{~m}$ a.s.1. 11.- Folgoso, Sierra del Caurel (Lugo), $600 \mathrm{~m}$ a.s.l. 12.- Santiso, rivière Ulla (A Coruña), $320 \mathrm{~m}$ a.s.l. 13.- Campofrío, rivière Odiel, Sierra de Aracena (Huelva), $340 \mathrm{~m}$ a.s.l. 14.- Rivera de la Nava, rivière Murtigas (Huelva), $480 \mathrm{~m}$ a.s.1. 15.- Huerta Hedionda, rivière Tavizna (Cádiz), $320 \mathrm{~m}$ a.s.l. 16.- El Bosque, Sierra de Grazalema (Cádiz), $300 \mathrm{~m}$ a.s.l. 
Thus, either the abdomen was cut from the rest of the body or the entire body without wings was macerated in hot $10 \% \mathrm{KOH}$ for a few minutes, then transferred into acetic acid ( $96 \%$ ). Thereafter, the translucent genitalia were used for determination. In the case of new species, genitalia were transferred into clove oil on a slide and figures were prepared with a drawing mirror at a Leitz MZ 3 Kombi stereo microscope (40 - $160 \mathrm{x}$ magnification). If not stated otherwise, specimens are deposited in the collection of F. Cobo (Universidad de Santiago de Compostela, Spain), type specimens and some material (Limnologische Fluss-Station Schlitz, Germany).

\section{Results}

\subsection{Dixidae}

Dixa nebulosa Meigen, 1830

(12) 30 15-VII-1986, 80'1우 15-VII-1986; (13) $10^{\circ}$ 11-VII-1990; (14) 440'4ㅇ 10-VII-1990; (15) $230^{7} 1$ \% 6-VIII-1986, $10^{\top 1} 1$ 19 14-VII-1990.

Distribution: widespread in Europe.

Dixa puberula Loew, 1849

(3) 60"1919-IX-1986; (4) 30'3ㅇ, 1 ? 17-IX-1986, $180^{\circ 14} 14$ 17-IX-1986, 60'5\% 21-IX-1986 ; (5) 20' 5VII-1995; (8) $190^{\prime 2} 2$ 11-X-1988 ; (9) $20^{\prime \prime 1} 1$ 2-XI1985 ; (10) $20^{\prime} 1$ ㅇ 19-VII-1985 ; (12) $180^{\prime \prime} 15$-VII1986, 330' 15-VII-1986 ; (14) 10' 10-VII-1990 ; (15) 10' 6-VIII-1986 ; (16) 10' 12-VII-1990.

Distribution: widespread in Europe.

Dixa submaculata Edwards, 1920

(13) 30' 2-XI-1985

Distribution: widespread in Europe.

Dixa cfr. submaculata Edwards, 1920

(4) 1 17-IX-1986

Dixa cfr. nebulosa Meigen, 1830

(13) 1 우 2-XI-1985

Dixa spec.

(5) 1 아 5-VII-1995; (6) 1 우 3-VII-1995; (13) 1911 VII-1990

\subsection{Thaumaleidae}

Thaumalea miki Edwards, 1929

(2) 10' 10-IX-1986 (first record for Andorra)

Distribution: Pyrenees, Alps and Carpathians.

Thaumalea pyrenaica Edwards, 1929

(4) 20' 21-LX-1986
Distribution: Pyrenees.

Thaumalea verralli Edwards, 1929

(2) 10' 10-IX-1986 (first record for Andorra)

Distribution: British Isles, Western Europe.

\subsection{Empididae}

\section{Hemerodromiinae}

Hemerodromia adulatoria Collin, 1927

(9) $50^{\circ} 4$ 우 21-VIII-1985, 50' 2ㅇ 23-VIII-1985; (11) $20^{\circ}$

2 \% 4-VIII-1985 ; (12) 40" 8 \% 15-VII-1986.

Distribution: Sweden, Great Britain, Germany, France, Spain.

Hemerodromia baetica Collin, 1927

(5) 10' 5-VII-1995

Distribution: Great Britain, Belgium, France, Spain (Andalusia, where the senior author collected specimens in the gardens of Alhambra).

Hemerodromia gaditana nov. spec.

Type locality: Huerta Hedionda, river Tavizna, (Cádiz), U.T.M. 30STF7767, $320 \mathrm{~m}$ a.s.l.

Type material: Holotype male, Huerta Hedionda, river Tavizna (Cádiz, Spain), 14-VII-1990, in coll. of the senior author at the Limnologische Fluss-Station Schlitz (Germany). Allotype female, same locality and data as holotype. Paratype $10^{7}$ as holotype.

Derivatio nominis: from Latin gaditanus-a, name of the inhabitants of Gades, former name of Cádiz.

Description

Head yellowish, eyes black. Hind margin of head (occiput) brownish black. Antennae and mouth-parts brown. Thorax yellow, mesonotum without any longitudinal bar, legs entirely yellow, including the $5^{\text {th }}$ tarsus segments. Wing venation typical of the genus, wing length 2.2-2.4 mm (approximate measure, specimens newly emerged).

Abdomen yellow, tergites 2-6 brown. Genitalia (Fig. 2) with a small hypandrium, aedeagus elongate straight, slightly bent basally; in the distal half with a transverse row of small setae and two large sclerotized hooks. Parameres shorter than aedeagus, basally bent, serrate along the distal margin and with a subapical triangular tip. Periandrium elongate, slightly bent dorsally, distally setose. Epandrium consists of a basal horizontal part with a basal and distal hook, and an upright part with four prominent hooks, two on the distal half along the upper horizontal margin and two on the vertical margin of the upright part. 


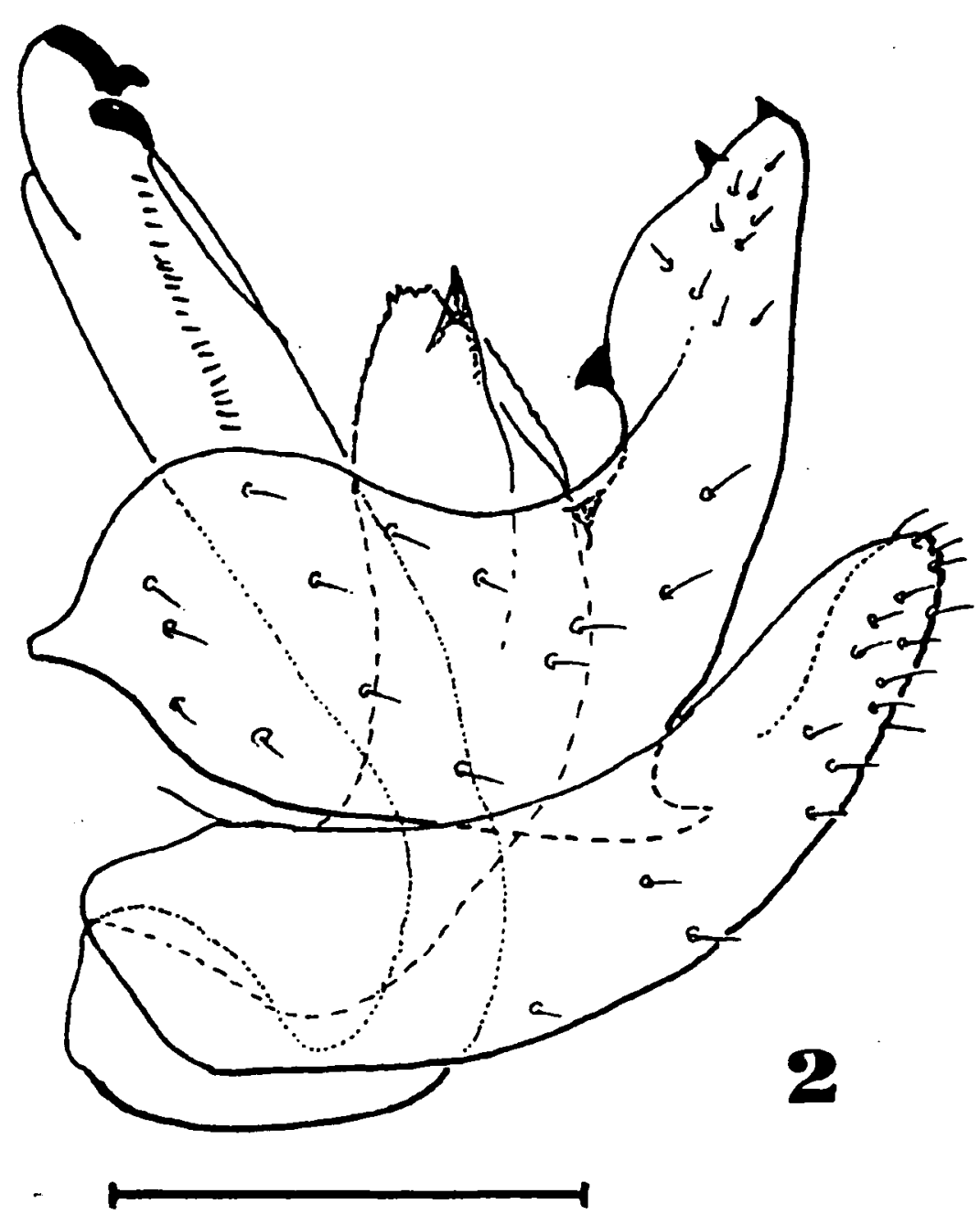

Fig. 2. Hemerodromia gaditana nov. spec. Genitalia, lateral view. Fig. 2. Hemerodromia gaditana nov. spec. Genitalia, vue latérale.

\section{Relations}

The shape of the genitalia, especially the epandrium, is unmistakable. Vaillant \& Gagneur (1998a) and Vaillant \& Moubayed (1998b) recently described several new species of the genus from North Africa and Lebanon, but none of these seems to be a close relative of the new species.

\section{Hemerodromia spec.}

(5) 19 5-VII-1995; (7) 1 우 4-VII-1995; (10) 1 우 23VIII-1985

\section{Chelifera spec.}

(4) 1ㅇ 17-IX-1986; (9) 29 21-VIII-1985, 19 4-IX1985 .

\section{Clinocerinae}

Wiedemannia (s. str.) mirousei Vaillant, 1956

(9) $20^{\circ} 2$ 2 21-VIII-1985, 40769 23-VIII-1985, 6077\% 4IX-1985, 10' 2-XI-1985

Distribution: A species of the W. rhynchops-group, that shares several endemisms in mountainous areas in Europe; probably $W$. mirousei is restricted to the Pyre- nees and the Cantabrian mountains (first record for Spain).

Wiedemannia (Chamaedipsia) digitata Vaillant \& Vinçon, 1986

(4) $10^{\circ} 19$ 17-XI-1986

Distribution: described from the French Pyrenees (Vaillant \& Vinçon 1986) ; first record for Spain.

Wiedemannia (Philolutra) fallaciosa (Loew, 1873)

(1) 30'59 1-VII-1994

Distribution: widespread in Europe, Mediterranean area to Central Asia (with subspecies). Mentioned from Almeria by Vaillant \& Chvála (1973).

Wiedemannia (Philolutra) hygrobia (Loew, 1858)

(4) 110759 17-XI-1986

Distribution: widespread in central and southern Europe.

Wiedemannia (Philolutra) tiburica nov. spec.

Type locality: Ferreirós, river Ferreirós, Sierra del Caurel, (Lugo), U.T.M. 29 TPH 5020, 500 m a.s.l.

Type material: Holotype male, Ferreirós, river Ferreirós, Sierra del Caurel, (Lugo, Spain), 2-XI-1985, in the collection of the senior author at the Limnologische Fluss-Station, Schlitz, Germany.

Derivatio nominis: from Latin Tiburi-orum, name of the former inhabitants of the East Gallaecia mountains.

Description:

Body brownish. Head with 1 pair of ocellar bristles and 5-6 postocular bristles. Eyes dark brown, antennae and mouth-parts lighter brown. Body length $3.9 \mathrm{~mm}$. Pronotum with 1 pair of bristles, mesonotum with 5 pairs of dorsocentrals and 6 pairs of acrostichials, the caudal acrostichials between the $3^{\text {rd }}$ and $4^{\text {th }}$ dorsocentrals. Wing without stigma, wing length $3.5 \mathrm{~mm}$. Wing venation not with the typical X-shaped in the centre, but halfs of the $X$ separated by a short, straight vein. Legs brown, front femur $\left(f_{1}\right)$ distally and front tibia $\left(t_{1}\right)$ basally lighter brown.

Genitalia with a rectangular hypandrium, penis with an elongate filiform flagellum, more than half the length of the basal part. Basistyle rectangular with a simple, inconspicuous surstyle. Gonostyle consists of an oval, caudally semicircular part, and an anterior slightly bent finger-shaped part, on its inner side with an elongate, field of short strong setae. Cerci with 3-5 elongate hairs (Fig. $3:$ A, B).

Relations: the new species is a close relative of Wiedemannia (Philolutra) zwicki Wagner, (1982, Italy, France), $W$. (P.) pohoriana Horvat (1995, Slovenia), and $W$. 


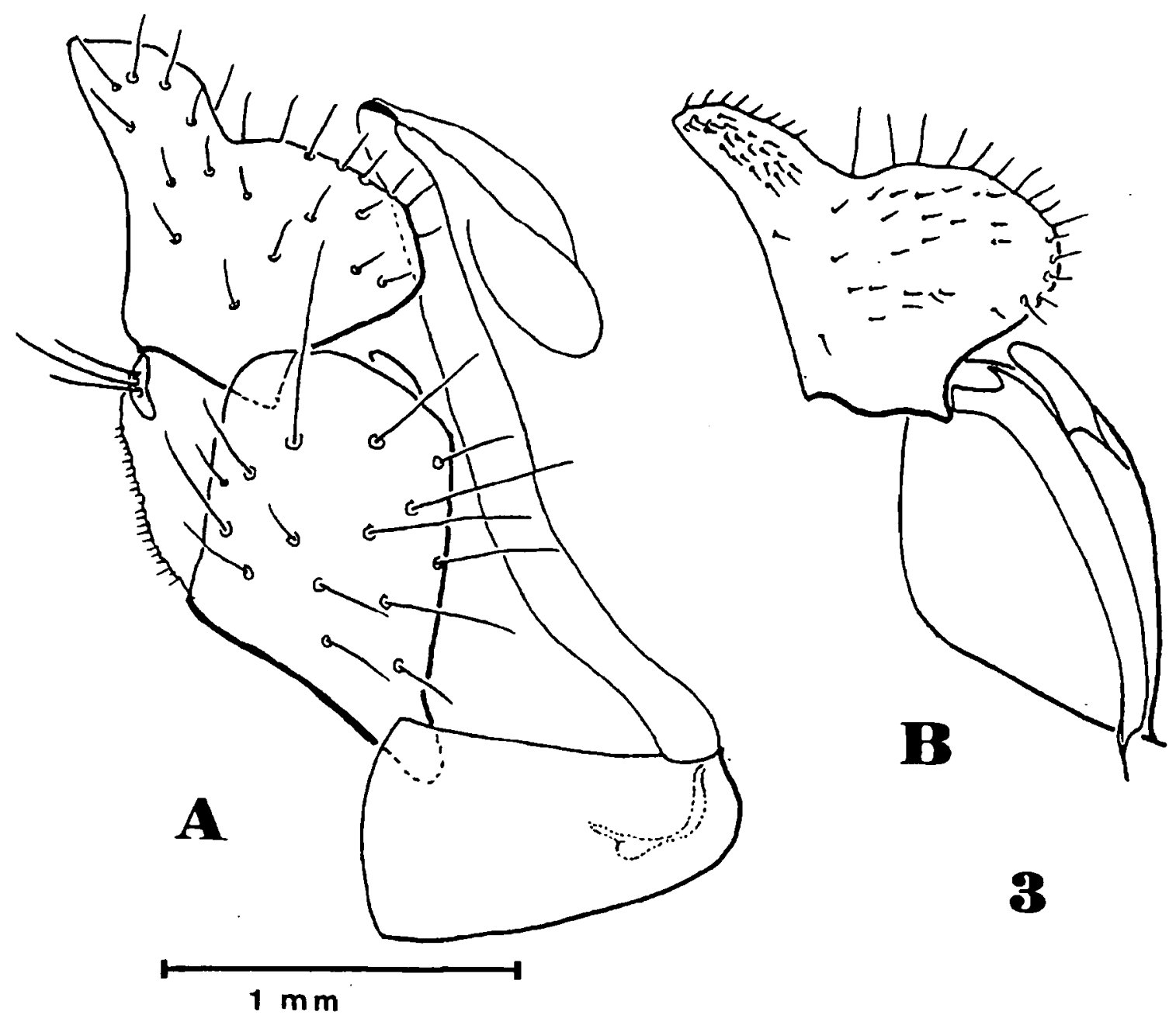

Fig. 3. Wiedemannia (Philolutra) tiburica nov. spec. A - genitalia, lateral view ; B - gonocoxite, gonostyle and surstyle, inner view.

Fig. 3. Wiedemannia (Philolutra) tiburica nov. spec. A - genitalia, vue latérale ; B - gonocoxite, gonostyle et surstylus, face interne.

(P.) kacanskae Horvat (1993, Bosnia and Hercegovina). All species differ in the shape of the gonostyle, it is higher than wide and appears slender in W. zwicki and $W$. kacanskae but is stout in W. pohoriana and the new species. The anterior, finger shaped portion is very thin in W. pohoriana, but broad in W. tiburica.

Wiedemannia (s. str.) spec. 1

(1) 19 1-VII-1994; (11) 2ㅇ 4-VIII-1985

Wiedemannia (s.str.) spec. 2

(1) 1이 1-VII-1994

Wiedemannia (Philolutra) spec.

(9) 1ㅇ 4-IX-1985

Clinocera (Kowarzia) barbatula Mik, 1880

(4) 10' 17-XI-1986

Distribution: widespread in central and southern Europe.
Clinocera (Kowarzia) madicola Vaillant, 1964

(9) 201우 4-IX-1985, 2003우 2-XI-1985; (11) $10^{7} 4$ VIII-1985 ; (13) 10' 11-VII-1990, 10'13-VII-1990, $10^{\circ}$ 11-VII-1990 ; (15) 20̛ 6-VIII-1986.

Distribution: widespread in central and southern Europe (first record for Spain).

Clinocera (Kowarzia) tenella (Wahlberg, 1844)

(4) 10' 17-XI-1986

Distribution: widespread in Europe, mentioned by Vaillant \& Chvála (1973) from Granada, north slope of Mt. Veleta (second record for Spain).

Clinocera (s. str.) nigra (Meigen, 1804)

(11) 10̛ 4-VIII-1985

Distribution: widespread in Europe and North Africa.

Clinocera (Hydrodromia) fontinalis (Haliday, 1833)

(9) 1074 4-IX-1985 (first record for Spain). 
Distribution: widespread in Europe (first record for Spain).

Clinocera (Hydrodromia) stagnalis (Haliday, 1833)

(9) $10^{\circ 1} 1$ 으 2-XI-1985

Distribution: widespread in the holarctic region.

Clinocera (Hydrodromia) wesmaeli (Macquart, 1835)

(4) 3우 17-IX-1986, 1우 17-XI-1986

Distribution: widespread in Europe (probably first record for Spain).

Clinocera spec.

(4) 2 \% 17-XI-1986

Dolichocephala ocellata (Costa, 1854)

(9) 10' 4-IX-1985 ; (14) 10' 10-VII-1990

Distribution: distribution not clear after revision of the group with description of several new species with a similar pattern of clear circular wing spots.

\section{Conclusion}

The declarative statement «new species for ...» was mainly referred to the Catalogue of Palaearctic Diptera concerning the respective families (Rozkosny 1990, 1998 ; Chvála \& Wagner 1989). The occurrence of Dixidae, Thaumaleidae and aquatic Empididae in Spain or Andorra is not surprising, because of their previous found in the French Pyrenees, as the distribution of aquatic insects in general agrees very often with the distribution of mountainous regions (Vaillant 1968a, 1968b, 1977). Almost every species mentioned in French Pyrenees thus will certainly occur two in Spanish Pyrenees and Andorra. Further, it is not surprising to find the Empidid Wiedemannia (s.str.) mirousei not only in Pyrenees but also in the western part of the Cantabrian mountains. We are certain that all the species mentioned above thus only form the basic stock of the fauna of the Iberian Peninsula. With further intensified studies in other regions of the area, new records and additional new species to Science are likely to appear.

\section{References}

Chvála M. \& Wagner R. 1989. - Diptera : Family Empididae. In : Sóos et Papp (eds) : Catalogue of Palaearctic Diptera, Vol. 6 Akadémia Kiado, Budapest : 228-336.

Horvat B. 1993. - Aquatic Empididae Fauna (Diptera) in Bosnia and Hercegovina. Scopolia, $28: 1-25$.
Horvat B. 1995. - Checklist of the aquatic Empididae recorded from Slovenia, with the description of one new species (Diptera). Acta Entomologia Slovenica, 3 (1) : 25-35.

Martinovsky J. \& Rozkosny R. 1988. - Diptera : Family Thaumaleidae. In : Sóos et Papp (eds) : Catalogue of Palaearctic Diptera, Vol. 3 Akadémia Kiadó, Budapest : 186-192.

Rozkosný R. 1990. - Diptera : Family Dixidae. In : Sóos et Papp (eds) : Catalogue of Palaearctic Diptera, Vol. 2 Akadémia Kiadó, Budapest : 66-71.

Schmid F. 1951. - Notes sur quelques Thaumaleides suisses et espagnols (Diptera, Nematocera). Bull. Inst. R.. Sci. Nat. belg., 27 : $1-6$.

Séguy E. 1929. — Etude systématique d'une collection de Diptères d'Espagne formée par le R.P. Longin Navas S.J. Mems. Soc. Ent. Esp., $3 \mathrm{a}: 30 \mathrm{p}$.

Strobl G. 1899. - Spanische Dipteren. VII. Theil. Wien ent. Ztg., 18 : 12-83.

Strobl G. 1906. - Spanische Dipteren. II. Beitrag. Mems R. Soc. esp. Hist. Nat., 3 : 271-422. (1905).

Strobl G. 1909. - Bombyliidae, Therevidae, Empididae. In : Czerny L. \& G. Strobl : Spanische Dipteren. III. Beitrag. Verh. Zool.bot. Ges. Wien, $59: 121-301$

Vaillant F. 1964. - Revision des Empididae Hemerodromiinae de France, d'Espagne et d'Afrique du Nord (Dipt.). Ann. Soc. Entomol. Fr., 133 : 143-171.

Vaillant F. 1967. - La répartition des Wiedemannia dans les cours d'eau et leur utilisation comme indicateurs de zones écologiques (Diptera, Empididae). Annls Limnol., 3(2) : 267-293.

Vaillant F. 1968a. - Les Diptères Dixidae des Pyrénées, des Alpes et des Carpates. Annls Limnol., 5(1) : 73-84.

Vaillant F. 1968b. - Les Diptères Thaumaleidae des Pyrénées. Annls Limnol., 4(1) : 81-84.

Vaillant, F. 1968c. - Quelques Empididae Hemerodromiinae des Pyrénées (Diptera). Annls Limnol., 4(1) : 85-93.

Vaillant F. 1977. - Les Diptères Thaumaleidae d'Europe. Ann. Soc. Entomol. Fr. (N.S.), 13(4) : 695-710.

Vaillant F. \& Chvála M. 1973. - Empididae Hemerodromiinae from Spain (Insectà, Diptera). Steenstrupia, $3: 57-64$.

Vaillant F. \& Vinçon G. 1986. - Quelques Clinocerini (Diptera, Empididae Hemerodromiinae) nouveaux ou mal connus des Pyrénées. Annls Limnol., 22(3) : 261-275.

Vaillant F. \& Gagneur J. 1998. - The Diptera Empididae Hemerodromiinae from western Algeria and the middle Atlas of Morocco. Ann. Soc. Entoml. Fr. (N.S.), 34 (4) : 365-384.

Vaillant F. \& Moubayed Z. 1998. - Notes sur les Diptères Empididae Hemerodromiinae du Liban. Revue fr. Ent. (N.S.), 20 (1-2) : 51-60.

Wagner R. 1982. - Über einige Empididae (Clinocerinae) aus den Alpen und aus Italien (Diptera, Empididae). Entomofauna, 3 (15) : 217-222.

Wagner R. 1995. - Empididen aus dem Mittelmeerraum (Diptera, Empididae : Hemerodromiinae und Clinocerinae). Acta Entomol. Slov., 3 (1) : 5-23.

Wagner R. \& Stauder A. 1993. - New Empididae from Madeira, the Azores and the Canary Islands. Bogatiana, Bolm. Mus. Municipal Funchal, 150 : 1-14. 